\title{
The Brazilian experience on prudential regulation and its impacts on the 2008 financial crisis
}

\author{
ROGÉRIO SOBREIRA*
}

The Brazilian economy was severely hit by the 2008 crisis. In the beginning of the crisis, the vast majorities of the economic agents and authorities thought that Brazil could face some sort of decoupling since some macroeconomic fundamentals were very good. What we saw, however, was that the Brazilian economy was not decoupled, and expectations faced a huge deterioration soon after the bankruptcy of Lehman Brothers in September 15th. Two aspects regarding the impact of crisis in Brazil, however, deserve a great deal of attention: (a) although deep, the impact did not last for a long time. Actually, the GDP growth experienced a good recovery in the second quarter of 2009, showing that the health of the Brazilian economy was good; (b) the Brazilian banking system performed very well during the crisis, although we cannot say the system was not in danger in the worst time of the crisis. In spite of the confidence crisis faced by the banking system, it showed a great deal of resilience. In this aspect, we argue that the restructure faced by the banking system in the aftermath of the Real Plan, as well as the development of a solid supervision regulation helped a lot the system to avoid the systemic crisis that was an open possibility to the Brazilian banking system in the end of 2008. These notes, thus, discusse why the Brazilian banking system performed pretty well in the 2008 financial crisis and how the Brazilian banking (and prudential) regulation can be taken as responsible for this good performance. More specifically, the paper back to the middle of the 1990s, when the Real Plan was implemented, in order to understand the role played by the restructuring of the Brazilian financial system in helping to pave the way to the great resilience experienced by the Brazilian banking system during the 2008 crisis. More specifically, the prudential regulation that was

\footnotetext{
* Associate Professor of Economics and Finance, Brazilian School of Public and Business Administration (EBAPE), Getulio Vargas Foundation (FGV), E-mail: rogerio.sobreira@fgv.br. These notes are based on the article Sobreira, R. and de Paula, L. (2010). "The 2008 Banking Crisis and Banking Behavior in Brazil: The Role of Prudential Regulation”, Journal of Innovation Economics, n. 6, pp. 77-93.
} 
implemented in Brazil in the aftermath of the Real Plan seems to play a decisive role in the resilience of the system nowadays.

\section{RESTRUCTURING OF THE BRAZILIAN BANKING SYSTEM IN THE AFTERMATH OF REAL PLAN}

Before the implementation of the Real Plan, many banks in Brazil attained great profits through 'floating' schemes. With high inflation, banks did their best when they were able to process deposits quickly. The speed with which Brazilian banks were able to process these transactions contributed to their technological innovation, which in turn helped Brazilian banks remain competitive when faced later with greater foreign competition. However, this speed with which transactions were processed was not used to transfer money efficiently from saving to investment units. Using deposit money, banks bought government securities protected against high inflation, rather than extending credit to the private sector, and were able to make substantial profits in just one night. There was almost no credit to the private sector under high inflation, because banks preferred to lend to the government since greater profits were available through floating. With the Real Plan, inflation was dramatically reduced as well as the potential profits from floating, which rapidly approached negligible levels The Real Plan made the mid-1990s a crucial period for Brazilian banks, because they were either forced out of the market or they were pressured to find new ways to make money, such as the advance of credit. Many large institutions were in grave trouble, and the banking sector needed reform in order to make the system more solid and to avoid a systemic crisis.

With the end of profits through floating, banks quickly had to find other means to produce profits. Expansion of credit was a viable option, and this was realized by both the banks and the government. The government increased reserve requirements for banks in an attempt to prevent a rapid expansion of the extension of credit that could be risky, but credit was greatly expanded. This expansion of credit was positive for the banks in the good times, but the situation rapidly deteriorated. Defaults on loans increased substantially between the introduction of the Real Plan and the end of 1995, and this led to liquidity issues for banks. State banks in particular faced extremely difficult times as they experienced high rates of default on top of deteriorating state finances (Puga, 1999). The Central Bank was facing increasing pressure to intervene directly in the banking system, and with the deteriorating financial health of many institutions it was forced to address the issues within the system and embark on a substantial reorganization of the sector.

The Central Bank of Brazil decided early on that it could not let the system as a whole collapse as it did in Venezuela with an estimated cost of $17 \%$ of GDP (Herrero, 2005, p. 72). It would be better to spend public money injecting liquidity into the system and on a restructuring incentive program than to bear the burden of rebuilding the entire system after a collapse. However, the Central Bank of Brazil decided to implement a restructuring program that would lead, at the end of 
day, to a more liberalized financial system. Thus, the main points of a program of liberalization of the financial market were more or less followed by the BCB. As pointed out by Demirgüç-Kunt and Detragiache (1998, p. 4), the liberalization of the financial system consists basically of: (a) ease or lift bank interest rate ceilings; (b) lower compulsory reserve requirements; (c) reduce government interference in credit allocations decisions; (d) privatize banks; (e) develop local stock markets; and (f) encourage entry of foreign financial intermediaries. The main measures implemented in the aftermath of the Real Plan can be summarized into two basic groups: structural measures, mainly liberalizing ones, and emergency measures.

\section{STRUCTURAL MEASURES: TOWARDS THE LIBERALIZATION OF THE FINANCIAL SYSTEM}

The reforms that were implemented at the beginning of July 1994 - soon after the implementation of the Real Plan — had the explicit aim at strength the financial system (Mendonça, 2006). Thus, in August 1994, in agreement with the Basle Accord (Basle, 1988), BCB published the Resolution 2099 establishing minimum capital limits for the operation of a bank that varied to the degree of risk in bank's assets. This measure is completely in line with the liberalization of the Brazilian financial system since we can consider the Basle Accord - mainly after the amendment of 1996 - as an accord that avoids direct intervention in the financial institutions and allows the banks not only to innovate, but also to increase their relationships with non-financial institutions (e.g., insurance companies). However, this measure sooner proved insufficient since the banks started to face liquidity crisis by that time, leading to a formation of a so called "pool of liquid resources" into the largest banks, with negative impacts on the interbank market. As a consequence, the BCB started to implement a series of emergency measures with the explicit purpose of strengthening the banking system.

One of the first measures was the creation of the PROER (Program of Incentives to the Restructuring and Strengthening of the National Financial System) in November 1995. It was created in order to assure the liquidity and solvency of the national financial system. It set up "a special line of financial assistance targeted to financial, administrative, operational and shareholder reorganizations that resulted in the transfer of control or the modification of a financial institution's corporate objective" (Puga, idem, p. 7). PROER was funded through compulsory deposits from financial institutions, so in principle the program had no impact on the fiscal budget. Participating institutions could defer their restructuring or modernization expenses for ten semesters in order to be freed up temporarily to implement the operational limits of the Basle I Accord.

The basic idea of PROER was to encourage mergers and acquisitions within the system. In order to promote the rapid consolidation of the banking sector, which would ideally lead to greater stability, PROER advanced tax incentives and credit facilities to participating institutions. Banks that were acquiring troubled 
institutions were given a line of credit below the market interest rate, and they were allowed to absorb the financial losses of the troubled institution on its balance sheet through tax write-offs. Two of the prime instances of the use of PROER funds are the acquisition of Banco Nacional by Unibanco and the acquisition of Banco Econômico by Banco Excel.

Also in November 1995, a month of sweeping resolutions addressing the problems in the banking system, the Credit Guarantee Fund (FGC) was created. With the establishment of the FGC came the guarantee of up to R $\$ 20,000.00$ for every deposit or investment titleholder in the case of a government intervention, out-ofcourt liquidation, bankruptcy, or perception on the part of the Central Bank of a state of insolvency in any financial institution after the beginning of the Real Plan. All financial institutions were required to contribute $0.024 \%$ of all balances in accounts covered by the FGC, and this guarantee had the effect of increasing public confidence in the banking system and preventing runs on banks with news of fragility. Public confidence in the system was crucial to restoring its health, and the deposit insurance provided by the FGC created enough peace of mind to prevent crippling runs on banks by the public. Other important measures created during the period 1995-1998 towards a more liberalized financial system — although the emergency nature of some of these measures is still present - are:

a. November 1995, Resolution 2212: sets a higher initial capital limit for the establishment of new banks;

b. March 1996, Provisional Measure 1334: delegates "responsibility for any cases of irregularities found at a financial institution to the audit companies or independent accounting auditors which reviewed the institution's books" (Puga, ibid., p. 7);

c. July 1996, Resolution 2302: obligates domestic financial institu- tions with branches or stock holdings in financial institutions abroad to comply with the operational limits of Basle I, based on consoli- dated financial figures, and raised the minimum capital limit for the constitution of such banks and branches abroad (ibid., p. 8);

d. May 1997, Resolution 2390: creates the Central Credit Risk System, where financial institutions must identify and inform the Cen- tral Bank on all customers who have debts greater than $\mathrm{R} \$ 50,000$;

e. June 1997, Resolution 2399: raises the minimum capital requirements for financial institutions, from $8 \%$ to $10 \%$ of all assets with risk;

f. November 1997, Circular 2,784: raises the minimum capital limit to $11 \%$, allowing financial institutions to adjust to the new measure until the end of 1998;

g. May 1998, Resolution 2493: opens the possibility of banks "selling part or all of their credit portfolios to corporations set up for that purpose, from then on denominated Financial Credit Securitization Companies (CSCFs)" (ibid., p. 8);

h. December 1998, Resolution 2554: establishes that financial institutions should implement internal control systems that are in accordance with the Basle Committee.

Another important and structural measure was implemented in August 1998 
and deals with the restructuring the State-owned banks. Thus, in this month it was created the PROES (the Program of Incentives for the Reduction of the State's Participation in Banking Activities) whose primary goal was to reduce public sector participation in the financial system. There were a number of options for state banks under PROES. A state bank could use PROES to (i) help transform the state bank into a nonfinancial institution of development agency; (ii) finance the restructuring of state banks with the end goal of subsequent privatization; or (iii) to finance up to $50 \%$ of the cost of restructuring the state bank that is recapitalized by the state government. In practice, the federal government offered to reschedule state governments' debts in order to persuade state banks to be 'federalized,' at which point the federal government would either reorganize the bank for sale to a private institution or liquidate the institution.

With the use of PROER and PROES, the period from 1995 to 1998 saw a clear downsizing trend in the number of banks. Private and public banks alike saw decreases in the number of institutions as well as in the number of branches. In this aspect, it is important to notice that up until the mid-1990s, financial regulation in Brazil was strongly focused on the liabilities of banking institutions, including a minimum capital and net equity requirement, a limit on the diversification of risks, a limit of immobilization, and a limit on indebtedness. The aim of the Central Bank was to provide more liquidity for institutions facing problems with the end result of preparing them for tighter regulation and, in many instances, Central Bank intervention. By the time of the Real Plan, the focus on regulation had shifted from liability transactions to risk-weighted asset transactions, in line with the new philosophy of (prudential) regulation that was taking place all over the world.

Although this wave of prudential regulation can also be understood as an international movement involving and reacting to competitive advantages of banks internationally active in order to equalize their competitiveness, the main force behind it was the liberalization of financial markets that took place in the middle of 1980 s, mainly in US and UK. The idea behind this new prudential regulation was to provide incentive measures to banks to operate in sustainable and profitable ways rather than to use direct intervention (Carvalho, 2005, ibid.). Prudential regulation implies establishing policies for banks' behaviour and calling for the disclosure of information in order to avoid direct intervention. This requirement of disclosure of information, through quarterly statements and according to international reporting standards, as well as the presence of monitoring and supervisory bodies, is expected to deter banks from taking certain and great risks and, at the same time, to preserve the so-called efficiency and functionality in the transfer of funds from saving to investment units. The idea was to incentivize efficiency and financial innovation, thus making it in a banks' interest to operate according to prudential regulation standards. The rationale behind this new kind of regulation was that the threat to a financial institution and to the system as a whole arises from the risks taken in the banks' investments, so it was necessary to link equity capital to the size of the risks the institution was taking.

Along with prudential regulation and injection of liquidity into the system, the 
liberalization of the Brazilian financial system was followed by opening of the banking sector to more foreign institutions. Prior to the 1990s, there were restrictions placed on foreign entry into the Brazilian banking system. The Federal Constitution of 1988 made foreign entry an unclear issue, but it kept open the possibility of foreign financial institutions having access to the domestic market through special Congressional or presidential decisions made in the interest of the Brazilian government. With the instability of the banking system in the 1990s, the Brazilian government decided it was in its interest to stimulate foreign entry and to adopt it as a policy. With foreign entry would come increased competition, and it was believed that foreign institutions were more efficient than their domestic counterparts. Net interest margins and operational costs tended to be lower for foreign institutions, so less efficient firms would be forced to pull out of the market leaving only the strongest institutions to survive, making the system as a whole stronger in the process. As a consequence, the participation of foreign-controlled banks among the fifteen largest banks increased from $6.5 \%$ to $34 \%$ between 1994 and 1998 (Carvalho, 2000, p. 2).

\section{THE CONSOLIDATION TO THE NEW ENVIRONMENT}

The period from 1999-2006 was a dynamic time for foreign presence in the Brazilian banking system. The currency devaluation of the real in 1999, largely a result of a previously overvalued exchange rate as well as a shift to a floating exchange rate, created some macroeconomic instability that led to the first exits of foreign firms from the Brazilian system. There was the beginning of a consolidation of the participation of foreign institutions. During the 1999-2002 period, some very important acquisitions were made: Banco Santander bought Banco Bozano, Simonsen (which had itself acquired Banco Meridional previously), ABN AMRO bought the Banco do Estado da Paraíba (which was good for its consolidation of operations in the Northeast of Brazil, since ABN AMRO had previously acquired the state bank of Pernambuco), and the Banco do Estado de São Paulo (BANESPA) was sold at a privatization auction to Santander. During this period, though, domestic banks decided to participate aggressively in the privatization auctions, so foreign banks faced increasingly tough domestic competition. This same period also saw the exit of a few Portuguese banks from the Brazilian system. Deinternationalization of the banking system continued during the 2002-2006 period as problems in Latin-American operations, macroeconomic instability of Latin America, and domestic competition led to further exits from the Brazilian banking sector. Foreign entry had helped the system quite a bit as average operational costs of domestic banks decreased substantially. However, the return of the domestic banks as measured by the ROE has never been affected by the entry of foreign competitors, which seems to show that the impact of the foreign banks on the functionality of the Brazilian financial system has never been that high as seen in some other countries (Fachada, 2008). 
This period saw the consolidation of domestic banks, related to the fact that the share of assets held by foreign banks decreased from $53.8 \%$ in 2001 to $27 \%$ in 2006, as well as the consolidation of some foreign institutions as well, such as HSBC, ABN AMRO, and Santander.

Currently, there is a great deal of stability in the Brazilian banking system (Goldfajn, Hennings and Mori, 2003). There is increased participation of domestic private banks along with increased concentration in the banking sector. The number of public banks has kept stable since the completion of privatizations, with 12 public banks holding about $20 \%$ of banking equity. There is also stable participation on the part of foreign institutions as well. Foreign entry was very successful in Brazil, helping to fix the system after the Real Plan. Once a measure of stability was reached, foreign entry was abandoned as a policy as the system could simply be left to operate according to market forces. The endurance and strength of the Brazilian system is evidence of the great degree of stability and regulation achieved, due to foreign entry and increased prudential regulation among other things.

At the same time that prudential regulation took hold in Brazil, foreign entry began increasing in the banking sector as well. Foreign entry provided increased competition, which helped Brazilian banks decrease their operation costs and increase efficiency under the new macroeconomic conditions. Foreign banks also increased the stability of the system, so much so that the Brazilian banking system is now much more solid than it ever was and no longer relies on foreign institutions to keep it stable. Domestic private institutions have increased their share in the system while consolidating their numbers, and government participation in the sector decreased after the privatizations of the mid-1990s and has remained fairly constant since. The Brazilian banking system effectively avoided systemic crisis in the mid-1990s, and it developed a solid framework of prudential regulation that has allowed it to weather financial shocks fairly well ever since.

Regarding specifically the changes in banking supervision that were implemented during the restructuring process, it is important to notice that the Central Bank of Brazil and the Ministry of Finance noticed that the fragility could not be considered a feature only of the banks. The supervisory laws could also be considered inadequate for the times of price stability (Moura, 1998). Thus, we may say the restructure faced by the Brazilian banking system in the aftermath of Real Plan helped to create a more resilient system that was able to deal with the 2008 crisis.

\section{THE POLICY RESPONSE TO THE 2008 CRISIS}

The Brazilian government tackled the initial effects of the financial turmoil with a set of actions designed to solve the severe liquidity problem faced by the economy soon after the bankruptcy of Lehman Brothers. The initial measures focused the reserve requirements. The main measures were the following:

- raising the value to be deducted in the calculation of the reserve requirements of the time deposits; 
- decreasing in the reserve ratio of the demand deposits from $45 \%$ to $42 \%$;

- decreasing in the reserve ratio of the time deposits from $100 \%$ to $30 \%$;

- decreasing $(40 \%)$ in the reserve ratio of the time deposits of the biggest banks that acquire the credit operations of the smallest banks.

These measures were expected to increase the supply of money in the economy by US\$ 22 billions. As a matter of fact, the Central Bank promised to increase the supply of money by US\$ 50 billions with those measures. In this aspect, it is particularly noticeable the decision of the government to allow the two biggest public commercial banks (Banco do Brasil and Caixa Econômica Federal) to acquire participations in private financial institutions without any need for public bid. The aim of this measure was not only to support small financial institutions, but mainly to make the credit supply greater. Another incentive to make private financial institutions supply of credit greater was a penalty in the reserve requirement of time deposits. The reserves depositary institutions should hold against time deposits consisted of public securities that pay interest on required reserve balances. The new measure led the Central Bank to cease to pay interest on $70 \%$ these funds as long as the biggest institutions avoid to advance credit and/or to acquire credit operations of smallest banks (and other financial institutions).

Together with those incentive measures, the Brazilian federal government also decided to increase directly the credit supply of the economy through new credit lines at the Brazilian Development Bank (BNDES) and Banco do Brasil. Those lines were advanced to fund investment expenses and to finance working capital. At the same time, the government created new credit lines at Caixa Econômica Federal to finance the acquisition of consumer goods.

Another important set of measures was related to development of the discount window procedures - that increased the term of the discount window credit up to 359 days against the 90 days previous term, as well as led to an improvement of the pricing of the assets delivered as collateral — and of the Credit Guarantee Fund (FGC), whose equity that could be used to support acquisitions of troubled institutions was increased from $20 \%$ to $50 \%$. The Central Bank also announced the creation of a special type of time deposit whose minimum term was 6 months and was backed by the FGC up to R $\$ 20$ millions by depositor (Mesquita, Torós, 2010, p. 15). According to those authors, this time deposit played a decisive role in the restoration of the confidence on the health of the small banks (idem).

By the end of 2008, the government turned your attention to the performance of the GDP. As a consequence, some fiscal measures were implemented, in order to incentive the consumer and investment expenses such as the reduction of the financial operations tax to finance the acquisition of consumer goods from $3.38 \%$ to $0.38 \%$. One of the main measures was the reduction in the income tax and the tax on manufactured goods (IPI). On the other hand, the primary surplus target was reduced to $2.5 \%$ of GDP against the previous $3.8 \%$ giving more fiscal room to increase the government spending to offset the negative impact of the financial turmoil. Finally, in the middle of 2009 the government decided to reduce the long- 
term rate of interest (TJLP) from $6.25 \%$ per year to $6 \%$ per year, helping to facilitate the advance of long-term credit supply by the Brazilian National Development Bank (BNDES).

A close look at the measures to compensate the negative impact of the crisis shows that the Brazilian government opted for incentive measures to increase credit supply and consumer and investment spending instead direct government spending. In this aspect, it is not possible to say that the government policy to deal with the effects of the crisis was a traditional Keynesian policy. The reason for this choice, apparently, can be found in the importance government gives to fiscal discipline that helps to avoid a spike in the risk aversion related to the Brazilian economy that would lead to a worsening in the capital flows to the economy.

\section{CONCLUSION: LESSONS TO BE LEARNED}

The restructuring of the Brazilian banking system prevented a crisis that seemed likely. The reforms matched the needs of the national and international contexts to create a stronger financial system. Mergers and acquisitions by both domestic and foreign institutions have increased concentration, and in doing so, saved insolvent banks without a great expenditure of federal funds. Programs such as PROER and PROES helped to increase remarkably the efficiency and resilience of the system. Foreign bank's entry also helped to increase efficiency and introduced new technology to the Brazilian banking system, although such penetration did not contributed to the reduction of the net interest margin of the whole banking sector. These measures combined left reversed Brazil's course from heading towards a systemic crisis. The prudential regulation apparatus implemented in the aftermath of the Real Plan also played a very important role in the resilience of the banking system.

The main lessons to be learned from the 2008 crisis regarding the behaviour of the Brazilian banking system are:

a. A strong prudential regulation seems to be very important, although too much prudential regulation could harm the system, affecting negatively its efficiency;

b. A better monitoring framework is important to give more transparency to the exposition of banks and non-financial companies, as well as standardization of derivatives contracts and limit their liquidation to futures exchanges (Mesquita, Torós, ibid., p. 16);

c. The entry of foreign banks played a decisive role. Foreign competitors seemed important to make the system more solid;

d. A high degree of openness is not necessarily good. In fact, since the Brazilian banking system is strongly domestic oriented and has a low degree of openness, it avoided to be engaged in financial operations with a high risk/return relationship;

e. The too big to fail philosophy lead to the moral hazard problem, but the 
alternative is not to let the bigger banks fail. It is definitely necessary to avoid the systemic crisis;

$\mathrm{f}$. The relaxation of prudential regulation does not seem to be positively related to the increase of credit supply. Actually, banks seem more prone to be engaged in more risk operations as a consequence of the relaxation in the regulation.

\section{REFERENCES}

ANDIMA (1995), Os Caminhos da Estabilização, Rio de Janeiro, Andima. BASLE (1988), International Convergence of Capital Measurement and Capital Standards.

BASLE, Bank for International Settlements. BELAISCH, A. (2003), ”Do Brazilian banks compete?, IMF Working Paper 03/113.

CARVALHO, F. (2000), "New competitive strategies of foreign banks in large emerging economies: The case of Brazil", Banca Nazionale Del Lavoro Quarterly Review, 213, July.

CARVALHO, F. (2005), "Inovação financeira e regulação prudencial: Da regulação de liquidez aos acordos de Basileia”, in Sobreira, R. (org.), Regulação Financeira e Bancária, São Paulo, Atlas.

CLAESSENS, S., DEMIRGUC-KUNT, A., HUIZINGA, H. (2001), "How Does foreign bank entry affect domestic bank market? I'Journal of Banking and Finance, 25, 891-911.

DEMIRGUÇ-KUNT, A., DETRAGIACHE, E. (1998), "Financial liberalization and financial fragility" Washington, IMF Working Paper WP/98/83, June.

FACHADA, P. (2008), “Foreign banks' entry and departure: The recent Brazilian experience”, $B C B$ Working Paper 164, June.

GOLDFAJN, I., HENNINGS, K., MORI, H. (2003), Brazil's financial system: Resilience to shocks, no currency substitution, but struggling to promote growth, Center for Research on Economic Development and Policy Reform. Stanford University. Working Paper 170.

HERRERO, A. (2005), Determinants of the Venezuelan banking crisis of the mid-1990s: An event history analysis, Nueva Época, XIV (1), 71-115.

IBGE/ANDIMA (1997), Sistema Financeiro: Uma Análise a Partir das Contas Nacionais, Rio de Janeiro, IBGE/Andima.

LISTFIELD, R., F. MONTES-NEGRET, F. (1996), Brazil's efficient payment system: A legacy of high inflation, Washington, The World Bank, Policy Research Working Paper 1680.

MENDONÇA, A. (2006), Prudential regulation and safety net: Recent transformations in Brazil, Mimeo.

MESQUITA, M., TORÓS, M. (2010), Considerações sobre a atuação do Banco Central na Crise de 2008, Brasília, Banco Central do Brasil, Working Paper 202, March.

MOURA, A. (1998), A study of the banking supervision in Brazil, Sao Paulo, EAESP/FGV/ NPP. Report 19.

PUGA, F. (1999), The Brazilian Financial System: Recent Restructuring, International Comparisons, and Vulnerability to a Foreign Exchange Crisis, Mimeo.

VALOR (2009), "Brasil enfrentou ataque e corrida bancária na crise”, Interview of the former Director of Monetary Policy of the Central Bank of Brazil Mario Torós to Valor Econômico newspaper published in 13 Sept. 